\title{
ANALISIS SUBSTITUSI USAHATANI KOPI KE USAHATANI KAKAO DI DESA BUKIT MENYAN KECAMATAN BERMANI ILIR KABUPATEN KEPAHIANG
}

\author{
AN ANALYSIS OF COFFEE FARMING SUBSTITUTION INTO COCOA \\ FARMING IN BUKIT MENYAN VILLAGE BERMANI ILIR SUBDISTRICT \\ KEPAHIANG REGENCY
}

\author{
Novika Astira \\ Program Studi Agribisnis Fakultas Pertanian, Universitas Dehasen Bengkulu
}

\begin{abstract}
ABSTRAK
Lahan tanaman kakao berkembang rata-rata hampir $10 \%$ per tahun selama lima tahun terakhir dan hal tersebut merupakan suatu tingkat pertumbuhan yang sangat besar. Hal ini memacu terjadinya perubahan-perubahan yang terjadi dalam masyarakat petani kopi yang dianggap sebagai dinamika yang terjadi pada masyarakat petani yang pada dasarnya untuk memaksimalkan pendapatan. Tujuan penelitian ini, mengetahui faktor yang menjadi alasan petani melakukan substitusi usahatani, seberapa luas lahan petani kopi yang disubstitusikan, berapa besar pendapatan usahatani kopi sebelum dan setelah disubstitusikan. Metode penelitian ini meliputi metode penentuan lokasi dan waktu penelitian yaitu di Desa Bukit Menyan Kecamatan Bermani Ilir Kabupaten Kepahiang, metode pengumpulan data yaitu data primer dan data sekunder, metode pengambilan sampel yaitu metode sampling total sebanyak 57 orang. Penelitian dianalisis melalui analisis deskriptif, dan analisis pendapatan.

Alasan petani melakukan substitusi usahatani disebabkan oleh 3 (tiga) faktor yaitu jumlah tanggungan keluarga, penerimaan usahatani kopi, dan faktor lain-lain (meniru petani lain, meningkatkan taraf hidup, harga kakao lebih mahal, frekuensi panen lebih banyak). Alasan karena jumlah tanggungan keluarga adalah sebanyak 14 orang atau sebanyak $24.50 \%$. Sedangkan alasan petani karena penerimaan usahatani kopi adalah sebanyak 29 orang atau sebanyak $50.87 \%$, dan untuk alasan faktor lain-lain adalah sebanyak 14 orang atau sebanyak $24.50 \%$. Luas lahan petani yang disubstitusikan memiliki rata-rata $75.07 \%$ dari total luas lahan yang dimiliki oleh petani. Pendapatan rata-rata petani kopi sebelum melakukan substitusi usahatani adalah sebesar adalah sebesar Rp 15.829.000 per tahun Pendapatan ratarata petani kopi sesudah melakukan substitusi usahatani adalah sebesar Rp 23.248.000 per tahun.
\end{abstract}

Kata Kunci: Substitusi, usahatani kopi, usahatani kakao

\begin{abstract}
Cocoa crop land grown by average of nearly $10 \%$ per year over the last five years and it is a very large growth rate. This triggers the changes in coffee farming communities are considered as the dynamics that occur in the farming community which is basically to maximize income. The purpose of this study are to find out the factors that determine the reason of farmers to farming substitute, how much the area coffee farmers are substitutable, and how much income the coffee farming before and after substitutable. The research method
\end{abstract}


includes determined the location and timing of research in Bukit Menyan village of Bermani Ilir subdistrict Kepahiang Regency, collect the data are primary and secondary data, and choose 57 people as the sampling method. The study analyzed through descriptive analysis, and revenue analysis.

The reason farmers do farming substitution caused by three factors which the number of dependents, a coffee farming receipts, and other factors (imitating the other farmers, improve the living standard, the price of cocoa is more expensive and more frequent harvest). 14 people as the reason for the number of dependents are $24.50 \%$. While, 29 people as many as the coffee farming receipts are 50.87\%, and for 14 people of other factors are $24.50 \%$. The substituted of farmers area had an average is $75.07 \%$ of the total area owned by farmers. The median income for coffee farmers before making farming substitutions are amounted to Rp 15.829 million per year. Whereas, the average income of coffee farmers after farming substitution was Rp 23.248 million per year.

Keywords: substitution, coffee farming, cocoa farming

\section{PENDAHULUAN}

Pembangunan pertanian merupakan bagian terpenting dan tidak dapat dipisahkan dari pembangunan nasional. Hal ini didasarkan kenyataan bahwa sebagian besar rakyat Indonesia menggantungkan hidupnya pada sector pertanian baik di sektor perkebunan, tanaman pangan, peternakan dan perikanan. Sebagai salah satu sector pertanian, sub sektor perkebunan dan tanaman pangan memberikan sumbangsih yang cukup besar terhadap devisa Negara, selain itu juga berperan dalam meningkatkan taraf hidup petani (Awal, 2003).

Tanaman Kopi (Coffea sp.) merupakan tanaman yang sangat familiar di lahan pekarangan penduduk pedesaan di Indonesia. Jika potensi yang baik ini bisa kita manfaatkan tidaklah sulit untuk menjadikan komoditi ini menjadi andalan di sektor perkebunan. Hanya butuh sedikit perlakuan teknis budidaya yang tepat, niscaya harapan kita optimis menjadi kenyataan. Sebagian besar tanaman kopi perkebunan rakyat, dilakukan dengan penerapan teknologi budidaya yang masih terbatas. Bila penerapan teknologi budidaya di perkebunan kopi rakyat tersebut diperbaiki, produksinya bisa ditingkatkan (Rahardjo, 2012).

Kopi merupakan salah satu komoditas ekspor yang mampu menciptakan penyerapan tenaga kerja dengan melibatkan banyak sektor, karena pengusahaannya dimulai dari kebun sampai dengan penanganan industri hilir. Tanaman kopi sudah lama dibudidayakan baik oleh rakyat maupun perkebunan 
besar. Luas lahan perkebunan kopi di Indonesia cenderung berkurang. Jika pada tahun 2000 luas lahan 1.333.898 ha, maka pada tahun 2010, berkurang 154.055 ha dan sampai sekarang menjadi $1.179 .843 \mathrm{~h}$ (Rahardjo, 2012).

Tujuan pembangunan pertanian adalah meningkatkan pendapatan dan taraf hidup petani, meningkatkan dan menganekaragaman hasil, meningkatkan mutu dan derajat pengolahan produksi serta menunjang pembangunan wilayah (Saragih, 2003). Dengan demikian dinamika pembangunan ditandai dengan transformasi struktur ekonomi dan demografi, yang salah satunya terjadi fenomena perubahan lahan pertanian. Hal ini menjadi acuan masyarakat petani untuk mendapatkan pendapatan dari luar usahatani kopi yang diusahakannya ke usahatani lain seperti usahatani kakao (Widiono, 2008).

Kakao (Theobroma cacao, $L$ ) adalah salah satu komoditas perkebunan yang memiliki peranan penting dalam pembangunan, karena dilihat dari peran ekonomi ke depan dan ke belakangnya cukup besar. Ke belakang sebagai lapangan kerja bagi rumah tangga petani, buruh tani, dan penggunaan input pertanian. Kedepan memberikan kesempatan kerja dan berusaha di sektor, transportasi, industri makanan, rumah makan/restoran, dan industri minuman. Oleh karena itu pengusahaan perkebunan kakao tidak saja mampu menampung kesempatan kerja juga menjadi sumber pendapatan bagi sebagian masyarakat perdesaan dan perkotaan yang terikat dalam masyarakat kakao (Zainudin, 2010).

Kondisi tersebut meningkatkan animo masyarakat untuk mengembangkan perkebunan kakao. Beberapa tahun terakhir sangat besar, sumber daya lahan masih tersedia. Lahan tanaman kakao berkembang rata-rata hampir $10 \%$ per tahun selama lima tahun terakhir dan hal tersebut merupakan suatu tingkat pertumbuhan yang sangat besar. Luas area pertanaman kakao di Indonesia terus mengalami peningkatan sejak tahun 2002 hingga tahun 2013. Peningkatan tertinggi terjadi dalam dalam tahun 2013 yaitu seluas 270.147 Ha (22.64\%) (Vivanews, 2013).

Hal ini memacu terjadinya perubahanperubahan yang terjadi dalam masyarakat petani kopi yang dianggap sebagai dinamika yang terjadi pada masyarakat petani. Perubahan tentu tampak dalam jangka waktu tertentu, dirasakan dan diamati pada waktu sekarang dengan membandingkan dengan waktu yang lalu. Misalnya perubahan petani dalam melakukan kegiatan usahatani dalam hal ini pemindahan dari satu pola usahatani yang dimilikinya ke penggunaan lahan yang dirasakan oleh petani membawa 
perkembangan kearah yang lebih baik dan dapat meningkatkan kesejahteraan bagi petani dan keluarganya (Soejonosukonto, 2001).

Perubahan yang dilakukan oleh petani kopi pada dasarnya untuk memaksimalkan pendapatan, yaitu untuk meningkatkan kesejahteraan keluarganya agar lebih baik, berdasarkan keadaan penguasaan sumberdaya yang terbatas. Apabila sumberdaya yang terbatas ini sudah digunakan seoptimal mungkin, namun pendapatan masih juga belum mencukupi maka petani akan melakukan perubahan pada kesempatan ekonomi yang lain yang diharapkan dapat mencukupi kebutuhan keluarganya. Semua gejala tersebut menjadi fenomena yang sangat menarik untuk diteliti, sebab aktivitas serta orientasi petani kopi telah mengalami perubahan yang cukup berarti. Untuk itu perlu dilakukan kajian lebih mendalam tentang "Analisis Substitusi Usahatani Kopi Ke Usahatani Kakao Di Desa Bukit Menyan Kecamatan Bermani Ilir Kabupaten Kepahiang”.

\section{METODE PENELITIAN}

\section{Tempat dan Waktu}

Penelitian dilakukan di Desa Bukit Menyan Kecamatan Bermani Ilir Kabupaten Kepahiang. Pemilihan lokasi ini dilakukan secara sengaja (Purposive) dengan pertimbangan bahwa di Desa
Bukit Menyan Kecamatan Bermani Ilir Kabupaten Kepahiang telah banyak melakukan substitusi usahatani kopi menjadi usahatani kakao. Desa Bukit Menyan merupakan desa pertanian dimana penduduknya $70 \%$ bermata pencaharian sebagai petani. Jumlah penduduk Desa Bukit Menyan adalah 1039 jiwa yang terdiri dari laki-laki 533 dan 506 perempuan, jumlah Kepala Keluarga Desa Bukit Menyan adalah sebesar 301 KK. Penelitian ini dilaksanakan pada bulan Maret 2016, selama lebih kurang satu bulan.

\section{Jenis dan Sumber Data}

Data yang digunakan dalam penelitian ini adalah data primer dan data sekunder. Data primer diperoleh dari hasil wawancara langsung dengan para petani yang dijadikan responden dengan menggunakan daftar pertanyaan (kuisioner). Data sekunder diperoleh dari data yang sudah ada sebelumnya. Data ini akan diperoleh dari kantor-kantor dan instansi yang erat kaitannya dengan penelitian ini yaitu Kantor Kepala Desa, Dinas Pertanian.

\section{Pengambilan Sampel}

Populasi dan sampel dalam penelitian ini adalah petani yang melakukan substitusi usahatani kopi menjadi usahatani kakao. Pada daerah penelitian berdasarkan 
observasi awal yang dilakukan peneliti, populasi petani melakukan substitusi usahatani kopi menjadi usahatani kakao di Desa Bukit Menyan Kecamatan Bermani Ilir Kabupaten Kepahiang adalah sebanyak 57 orang yaitu semua petani yang mensubstitusikan usahataninya ke usahatani kakao baik sebagian atau semua lahan (tidak termasuk petani yang hanya mengusahakan usahatani kakao saja dari mulai berusahatani). Menurut Arikunto (2006) jumlah populasinya lebih kecil yaitu kurang dari 100 orang maka lebih baik diambil semua sehingga penelitiannya merupakan peneltian populasi selanjutnya "apabila subjeknya lebih besar yaitu lebih dari 100 orang dapat diambil dengan menggunakan sistem persentase yaitu antara 10\%-15\% atau 20\%-25\%". Sehubungan jumlah populasi dalam penelitian ini kurang dari 100 orang jadi peneliti mengambil semua populasi untuk dijadikan sampel penelitian. Penentuan sampel ditentukan dengan metode sampel total, yaitu suatu teknik pengambilan sampel dimana seluruh populasi dijadikan sampel (Suyanto, 2008). Sehingga semua petani melakukan substitusi usahatani kopi menjadi usahatani kakao di Desa Bukit Menyan Kecamatan Bermani Ilir Kabupaten Kepahiang adalah menjadi sampel yaitu sebanyak 57 orang.

\section{Metode Analisis Data}

Untuk menjawab beberapa tujuan yang diajukan dalam penelitian ini, maka data penelitian dianalisis melalui cara-cara berikut:

1. Alasan petani melakukan substitusi usahatani kopi

Untuk mengetahui alasan petani melakukan subsitusi usahatani kopi ke usahatani kakao dengan cara wawancara kepada petani yang melakakan substitusi usahatani kopi ke usahatani kakao di Desa Bukit Menyan Kecamatan Bermani Ilir Kabupaten Kepahiang dilakukan analisis Deskriptif. Menurut Suyatno (2008), metode deskriptif adalah suatu metode dalam meneliti suatu objek, suatu kelompok manusia, kondisi suatu sistem pemikiran ataupun suatu kelas peristiwa pada masa sekarang dengan tujuan untuk membuat deskripsi, gambaran atau lukisan secara sistematis, faktual dan akurat mengenai fakta-fakta, sifat-sifat serta hubungan antar fenomena yang diselidiki. 2. Luas lahan petani yang disubstitusikan Analisis data yang digunakan untuk mengetahui seberapa luas lahan petani yang disubstitusikan di Desa Bukit Menyan Kecamatan Bermani Ilir Kabupaten Kepahiang dilakukan analisis Deskriptif. Metode ini merupakan penjelasan atau pembahasan data yang diperoleh selama penelitian. Menurut Suyatno (2008), metode deskriptif adalah 
suatu metode dalam meneliti suatu objek, suatu kelompok manusia, kondisi suatu sistem pemikiran ataupun suatu kelas peristiwa pada masa sekarang dengan tujuan untuk membuat deskripsi, gambaran atau lukisan secara sistematis, faktual dan akurat mengenai fakta-fakta, sifat-sifat serta hubungan antar fenomena yang diselidiki.

\section{Pendapatan Usahatani Kopi Sebelum} dan Sesudah Substitusi

Untuk mengetahui berapa besar pendapatan Usahatani Kopi sebelum dan sesudah substitusi menggunakan rumus pendapatan (Boediono, 2002) yaitu diperoleh dengan cara mengurangkan total penerimaan dengan total biaya :

\section{$\mathbf{I}=\mathbf{T R}-\mathbf{T C}$}

Keterangan

I = Pendapatan (Income)

$\mathrm{TR}=$ Total Penerimaan $($ Total Revenue $)$

$\mathrm{TC}=$ Total Biaya $($ Total Cost $)$

Sedangkan untuk menghitung besarnya penerimaan menurut Samuelson dkk, (2003) ditentukan dengan menggunakan rumus sebagai berikut :

$\mathbf{T R}=\mathbf{P q} \cdot \mathbf{Q}$

Keterangan

$\mathrm{TR}=$ Total Penerimaan (Rp/bulan)

$\mathrm{Pq}=$ Harga Produk $(\mathrm{Rp} / \mathrm{Kg})$

$\mathrm{Q}=$ Jumlah Produk $(\mathrm{Kg})$

\section{HASIL DAN PEMBAHASAN}

\section{Gambaran Umum Desa Bukit Menyan}

Desa Bukit Menyan merupakan salah satu desa di Kecamatan Bermani ilir Kabupaten Kepahiang Provinsi Bengkulu terletak di sebelah Timur Kabupaten Kepahiang berbatasan dengan Sumatera Selatan (SUMSEL) luas Provinsi Bengkulu mencapai 32.365.6 Kilo Meter persegi untuk wilayah desa Bukit Menyan luas wilayah lebih kurang $480 \mathrm{Ha}$. Desa Bukit Menyan terletak dalam wilayah kecamatan Bermani ilir Kabupaten Kepahiang Provinsi Bengkulu.

a. Sebelah Utara berbatasan dengan Hutan Lindung

b. Sebelah Timur berbatasan dengan desa Batu Belarik

c. Sebelah Barat berbatasan dengan desa Taba Air Paug

d. Sebelah Selatan berbatasan dengan desa Embong Sido atau Keban Agung

Luas wilayah Desa Bukit Menyan lebih kurang $480 \mathrm{Ha}$, dimana $90 \%$ berupa daratan dan $10 \%$ persawahan dan sungai, iklim desa Bukit Menyan sebagaimana lainnya mempunyai musim kemaraw dan musim hujan. Penduduk desa Bukit Menyan mayoritas berasal dari suku jawa yaitu Jawa Timur, jawa Tengah dan Jawa barat. Namun demikian kegotongroyongan di desa Bukit Menyan masih sangat kompak, kemudian tradisi mufakat dan kearifan local yang lain dilakukan 
oleh masyarakat sejak awal bedirinya

Desa Bukit Menyan masih terjaga dengan baik, sehingga secara efektif dapat menghindari adanya benturan antar kelompok masyarakat.

Desa Bukit menyan mempunyai jumlah penduduk 1039 jiwa yang terdiri dari lakilaki 533, perempuan 506, jumlah KK 301. Tingkat pendidikan masyarakat Bukit Menyan pra Sekolah 162 orang, SD 339 orang, SMP 161 orang, SMA 23 orang dan Sarjana 8 orang dapat dilihat pada Tabel 1.

Karena Desa Bukit Menyan merupakan desa pertanian dan perkebunan maka penduduknya memiliki mata pencarian sebagai petani, tukang, buruh tani untuk lebih rinci dapat dilihat pada tabel 2.
Petani dalam hal ini adalah petani padi sawah, petani padi ladang, petani jagung, ubi kayu, kopi, sawit. Sedangkan untuk peternakan adalah kambing, ayam buras dan perikanan adalah kolam air tawar. Kondisi ekonomi masyarakat Desa Bukit Menyan secara kasat mata terlihat jelas perbedaannya antara rumah tangga yang berkategori miskin, sangat miskin, sedang dan kaya. Hal ini disebabkan karena mata pencahariannya di sector-sektor usaha yang berbeda-beda pula, sebagian besar di sector non formal seperti petani, usaha kecil, pembuatan makanan kripik, buruh bangunan, buruh tani, anyaman bambu dan di sektor formal seperti PNS pemda, honorer, guru dan tenaga medis.

Tabel 1. Tingkat Pendidikan Masyarakat Desa Bukit Menyan

\begin{tabular}{ccccc}
\hline Pra Sekolah & SD & SMP & SMA & Sarjana \\
\hline 162 orang & 339 orang & 161 orang & 23 orang & 8 orang \\
\hline
\end{tabular}

Sumber: Profil Desa Desa Bukit Menyan, 2016

Tabel 2. Mata Pencaharian Masyarakat Desa Bukit Menyan

\begin{tabular}{ccccc}
\hline Petani & Pedagang & PNS & Buruh & Ternak \\
\hline $70 \%$ & 21 orang & 13 orang & $5 \%$ & 150 orang \\
\hline
\end{tabular}

Sumber: Profil Desa Desa Bukit Menyan, 2016 


\section{Identitas Responden}

Berdasarkan hasil penelitian, diketahui bahwa umur petani di Desa Bukit Menyan Kecamatan Bermani Ilir Kabupaten Kepahiang disajikan pada tabel 4. Dari hasil penelitian diketahui rata-rata umur petani di Desa Bukit Menyan adalah 47,09 tahun, dengan kisaran 29 sampai 41 tahun. Petani yang berkategori tua sebanyak 18 orang atau $31.58 \%$, sedangkan petani yang umurnya dengan kategori sedang sebanyak 15 orang atau sebanyak 26,32\% dan untuk petani yang berkategori muda labih banyak bila dibandingkan dengan petani yang berkategori lain, yaitu sebanyak 24 orang atau sebanyak 42.10 $\%$. Berdasarkan rata-rata umur petani sebagian besar masih berada pada usia produktif. Usia produktif berhubungan dengan kemampuan kerja petani yaitu mempunyai kemampuan kerja lebih besar dibandingkan dengan anggota usia nonproduktif. Menurut Mubyarto (2001) bahwa umur 15 sampai 64 tahun merupakan usia produktif. Dengan usia yang produktif petani akan lebih memiliki kemampuan untuk berusaha semaksimal mungkin dan mencapai keberhasilan usahanya.

Berdasarkan hasil penelitian, diketahui bahwa jenis kelamin petani di Desa Bukit Menyan Kecamatan Bermani Ilir Kabupaten Kepahiang disajikan pada tabel 5. Dari hasil penelitian diketahui rata-rata jenis kelamin petani di Desa Bukit Menyan adalah laki-laki. Petani yang berkategori laki-laki sebanyak 57 orang atau $100 \%$, sedangkan petani yang jenis kelamin perempuan sebanyak 0 orang atau sebanyak $0.0 \%$. Berdasarkan rata-rata jenis kelamin semua responden adalah laki-laki yang jenis kelamin berhubungan dengan kemampuan kerja petani yaitu laki-laki mempunyai kemampuan kerja lebih besar dibandingkan dengan perempuan.. Menurut Syafuan (2013) bahwa jenis kelamin berpengaruh terhadap produktifitas kerja petani.

Tabel 4 Umur Petani Desa Bukit Menyan

\begin{tabular}{cccccc}
\hline No & Umur & $\begin{array}{c}\text { Jumlah } \\
\text { (jiwa) }\end{array}$ & Persen (\%) & Rata-rata & Kisaran \\
\hline 1 & $29-41$ & 24 & 42.10 & 47.09 & $29-65$ \\
2 & $42-54$ & 15 & 26.32 & & \\
3 & $55-65$ & 18 & 31.58 & & \\
\hline & Jumlah & 57 & 100 & & \\
\hline
\end{tabular}

Sumber: Data diolah, 2016 
Tabel 5 Jenis Kelamin Petani Desa Bukit Menyan

\begin{tabular}{cccccc}
\hline No & $\begin{array}{c}\text { Jenis } \\
\text { Kelamin }\end{array}$ & $\begin{array}{c}\text { Jumlah } \\
\text { (jiwa) }\end{array}$ & Persen (\%) & Rata-rata & Kisaran \\
\hline 1 & Laki-Laki & 57 & 100 & Laki-laki & - \\
2 & Perempuan & 0 & 0 & & \\
\hline & Jumlah & 57 & 100 & &
\end{tabular}

Sumber: Data diolah, 2016

Tabel 6. Pengalaman Berusahatani

\begin{tabular}{cccccc}
\hline No & Lama bekerja & $\begin{array}{c}\text { Jumlah } \\
\text { (jiwa) }\end{array}$ & Persen (\%) & Rata-rata & Kisaran \\
\hline 1 & $1-9$ & 8 & 14.04 & 16.42 & $1-25$ \\
2 & $10-17$ & 17 & 29.82 & & \\
3 & $18-25$ & 32 & 56.14 & & \\
\hline & Jumlah & 57 & 100 & & \\
\hline
\end{tabular}

Sumber: Data diolah, 2016

Dari penelitian yang dilakukan, diketahui pengalaman berusahatani di Desa Bukit Menyan Kecamatan Bermani Ilir Kabupaten Kepahiang disajikan pada tabel 6. Berdasarkan tabel 6 terlihat bahwa responden yang memiliki lama bekerja dengan kisaran 18-25 tahun merupakan jumlah tertinggi yaitu berjumlah 32 orang atau sekitar 56.14\%. Sedangkan responden paling sedikit memiliki lama bekerja adalah kisaran 1-9 tahun yaitu berjumlah 8 orang atau $14.04 \%$.

Dari uraian diatas terlihat bahwa sebagian besar petani rata-rata mempunyai pengalaman berusahatani kopi yang lama. Dengan pengalaman yang cukup lama, petani sudah memiliki kemampuan dan keterampilan yang relatif tinggi dalam mengembangkan usahataninya, apabila ia akan memulai suatu usahatani maka ia akan memiliki gambaran tentang apa yang harus dilakukan untuk meningkatkan produksi dan tingkat penerimaan usahataninya. Karena semakin lama petani berusahatani mereka lebih respon dan cepat tanggap terhadap gejala yang mungkin akan terjadi. Apabila pada akhirnya nanti mengalami suatu kegagalan mereka sudah tidak canggung lagi dalam melakukan perubahanperubahan dalam kegiatan usahatanianya. Dengan demikian berarti petani kopi sudah memberikan suatu keputusan yang berpengaruh terhadap proses substitusi 
usahatani yang dilakukan dengan harapan dapat lebih baik dari kegiatan usahatani yang dilakukan sebelumnya serta dapat memperbaiki ekonomi keluarganya (Yuanda, 2004).

\section{Faktor yang Menjadi Alasan Petani}

\section{Melakukan Substitusi Usahatani Kopi}

\section{ke Usahatani Kakao}

Berdasarkan hasil penelitian, diketahui bahwa alasan petani melakukan substitusi usahatani kopi ke usahatani kakao di Desa Bukit Menyan Kecamatan Bermani Ilir Kabupaten Kepahiang disajikan pada tabel 7. Berdasarkan tabel 7 terlihat bahwa alasan petani karena jumlah tanggungan keluarga adalah sebanyak 14 orang atau sebanyak 24.50\%. Sedangkan alasan petani karena penerimaan usahatani kopi adalah sebanyak 29 orang atau sebanyak $50.87 \%$, dan untuk faktor lain-lain adalah sebanyak 14 orang atau sebanyak $24.50 \%$. Dari penelitian yang dilakukan, diketahui jumlah tanggungan keluarga di Desa
Bukit Menyan Kecamatan Bermani Ilir Kabupaten Kepahiang disajikan pada tabel 8.

Paling sedikit responden mempunyai tanggungan keluarga dengan kisaran 1-2 orang yaitu berjumlah 11 orang dari 57 responden yang diteliti. Dengan rata-rata tanggungan responden 3 orang. Hal ini menunjukkan bahwa pada umumnya responden yang tinggal dalam satu rumah sebanyak 5 orang, yang berarti jumlah kebutuhan rumah tangga responden relatif besar, sedangkan kebutuhan semakin meningkat. Hal ini dapat dimengerti, karena dengan banyaknya tanggungan keluarga, maka pengeluaran semakin besar dan kebutuhan juga semakin tinggi sehingga kondisi ini akan merangsang kepala keluarga untuk bekerja lebih giat dan mudah untuk menerima perubahanperubahan yang terjadi pada usahataninya dengan harapan mengalami perubahan ke arah yang lebih baik dalam hal kemapuan untuk memenuhi kebutuhan keluarganya.

\begin{tabular}{clcc}
\multicolumn{4}{l}{ Tabel 7 Faktor Alasan Petani Melakukan Substitusi } \\
\hline No & \multicolumn{1}{c}{ Tanggungan } & $\begin{array}{c}\text { Jumlah } \\
\text { (jiwa) }\end{array}$ & Persen (\%) \\
\hline 1 & $\begin{array}{l}\text { Jumlah tanggungan } \\
\text { keluarga }\end{array}$ & 14 & 24.50 \\
2 & Penerimaan usahatani & 29 & 50.87 \\
3 & Faktor lain-lain & 14 & 24.50 \\
\hline & Jumlah & 57 & 100
\end{tabular}

Sumber: Data diolah, 2016 
Tabel 8 Responden Menurut Jumlah Tanggungan Keluarga

\begin{tabular}{cccccc}
\hline No & Tanggungan & $\begin{array}{c}\text { Jumlah } \\
\text { (jiwa) }\end{array}$ & Persen (\%) & Rata-rata & Kisaran \\
\hline 1 & $1-2$ & 11 & 19.29 & 3.88 & $1-6$ \\
2 & $3-4$ & 24 & 42.11 & & \\
3 & $5-6$ & 22 & 38.60 & & \\
\hline & Jumlah & 57 & 100 & & \\
\hline
\end{tabular}

Sumber: Data diolah, 2016

Hasil penelitian ini sejalan dengan hasil penelitian Marlena (2005) yang menunjukkan bahwa semakin banyak jumlah tanggungan keluarga, maka semakin tinggi motivasi kerja yang dimiliki oleh petani untuk melakukan perubahan usahatani.

Dari penelitian yang dilakukan, diketahui penerimaan sebelum substitusi usahatani di Desa Bukit Menyan Kecamatan Bermani Ilir Kabupaten Kepahiang disajikan pada tabel 9. Peneriman petani kopi sebelum dikurangi biaya, paling sedikit petani memiliki penerimaan dengan kisaran 35.700 .000 - 50.400 .000 yaitu berjumlah 3 orang dari 57 responden yang diteliti. Dengan rata-rata penerimaan petani Rp 17.889.000 per tahun. Hal ini menunjukkan bahwa pada umumnya petani memiliki penerimaan yang rendah karena di dukung oleh jumlah tanggungan keluarga yang banyak yang berarti jumlah kebutuhan rumah tangga responden relatif besar.

Menurut Mubyarto (2002), ciri khas kehidupan petani adalah perbedaan pola pendapatan dan pengeluarannya. Pendapatan petani hanya diterima setiap musim panen, sedangkan pengeluaran harus diadakan setiap hari, setiap minggu atau kadang-kadang dalam waktu yang sangat mendesak sebelum panen tiba. Selain itu apabila saat panen tiba biasanya harga yang diterima oleh petani sangat rendah.

Besarnya jumlah pengeluaran yang harus dilakukan terhadap usahataninya maka para petani akan mencoba inovasi yang baru yang dapat mengurangi pengeluaran usahataninya, hal ini akan berdampak pada penerimaan yang mereka miliki. Dengan semakin kecilnya jumlah penerimaan yang mereka dapatkan dari usahatani kopi maka mereka akan mencoba untuk melakukan substitusi usahatani kakao yang dapat memberikan penerimaan yang cukup baik untuk memenuhi kebutuhan keluarganya. Dalam penelitian Syafuan (2007) penerimaan usahatani mempunyai hubungan yang nyata dengan perubahan pola usahatani. 
Tabel 9 Penerimaan Petani Sebelum Substitusi

\begin{tabular}{|c|c|c|c|c|c|}
\hline No & $\begin{array}{c}\text { Penerimaan sebelum } \\
\text { substitusi }\end{array}$ & $\begin{array}{l}\text { Jumlah } \\
\text { (jiwa) }\end{array}$ & $\begin{array}{c}\text { Persen } \\
(\%)\end{array}$ & Rata-rata & Kisaran \\
\hline \multirow{3}{*}{$\begin{array}{l}1 \\
2 \\
3\end{array}$} & $6.300 .000-21.000 .000$ & 37 & 64.91 & \multirow{3}{*}{$\begin{array}{c}17.889 .00 \\
0\end{array}$} & \multirow{3}{*}{$\begin{array}{l}6.300 .000- \\
50.400 .000\end{array}$} \\
\hline & $21.000 .000-35.700 .000$ & 17 & 29.82 & & \\
\hline & $35.700 .000-50.400 .000$ & 3 & 5.26 & & \\
\hline & Jumlah & 57 & 100 & & \\
\hline
\end{tabular}

Sumber: Data diolah, 2016

Faktor lain-lain yang menjadi alasan petani mensubstitusikan usaha lainnya selain faktor jumlah tanggungan dan penerimaan mereka yang rendah yaitu dengan alasan meniru petani lain yang telah sukses dalam mensubstitusikan usahatani kopi ke usahatani kakao, selain itu karena alasan untuk meningkatkan taraf hidup, karena harga kakao lebih mahal dan frekuensi panen lebih banyak.

Berdasarkan hasil penelitian, diketahui bahwa alasan petani melakukan substitusi usahatani kopi ke usahatani kakao karena alasan faktor lain-lain di Desa Bukit Menyan Kecamatan Bermani Ilir
Kabupaten Kepahiang disajikan pada tabel 10.

Berdasarkan tabel 10 terlihat bahwa alasan petani karena faktor lain-lain diantaranya karena alas an meniru petani lain adalah sebanyak 6 orang atau sebanyak $42.86 \%$. Sedangkan alasan petani karena meningkatkan taraf hidup adalah sebanyak 2 orang atau sebanyak $14.28 \%$, alas an karena harga kakao lebih mahal adalah sebanyak 3 orang atau sebanyak $21.43 \%$ dan untuk alasan frekuensi panen lebih banyak adalah sebanyak 3 orang atau sebanyak $21.43 \%$.

\section{Tabel 10 Alasan faktor lain-lain}

\begin{tabular}{clcc}
\hline No & \multicolumn{1}{c}{ Tanggungan } & Jumlah (jiwa) & Persen (\%) \\
\hline 1 & Meniru petani lain & 6 & 42.86 \\
2 & Meningkatkan Taraf Hidup & 2 & 14.28 \\
3 & Harga kakao lebih mahal & 3 & 21.43 \\
4 & Frekuensi panen lebih banyak & 3 & 21,43 \\
\hline & Jumlah & 14 & 100
\end{tabular}

Sumber: Data diolah, 2016 
Luas lahan Petani yang Disubstitusikan

Menurut Kustiawan (2002) pengertian substitusi usahatani menyangkut transformasi dalam pengalokasian sumberdaya lahan dari satu penggunaan ke penggunaan lainnya. Perkembangan kehidupan telah membuat substitusi usahatani kopi ke usahatani kakao sulit dihindarkan. Jumlah tanggungan keluarga terus bertambah, tuntutan peningkatan kualitas kehidupan, semuanya itu mendorong terjadinya substitusi usahatani.

Luas lahan petani yang melakukan substitusi usahatani kopi ke usahatani kakao bervariasi dari keseluruhan luas lahan kopi yang mereka miliki dari tahun 2011 sampai tahun 2016, Rata-rata lahan petani yang disubstitusikan sebesar 75,07 $\%$ dari total lahan usahatani kopi yang mereka miliki. Untuk lebih jelasnya dapat dilihat pada Tabel 11 .

Tabel 11 memperlihatkan bahwa jumlah petani yang paling besar melakukan substitusi usahatani antara $75-100 \%$ dari keseluruhan luas lahan usahatani kopi yang mereka miliki pada tahun 2011 sampai tahun 2016 sebanyak 37 orang atau $64.91 \%$, sedangkan persentase sedang antara 50-74\% sebanyak 13 orang atau $22,80 \%$ dan untuk persentase kecil antara 25-49\% masing-masing-masing sebanyak 7 orang atau 12,28\%.
Mensubstitusikan usahatani kopi ke usahatani kakao menjadi pilihan petanipetani yang tinggal di Desa Bukit Menyan Kecamatan Bermani Ilir Kabupaten Kepahiang propinsi Bengkulu. Rata-rata luas lahan usahatani kopi petani sebelum substitusi adalah sebesar 0.77 Ha. Sementara setelah terjadinya substitusi usahatani rata-rata lahan usahatani kopi adalah sebesar 0.35, ini menunjukkan terjadinya pengurangan luas lahan usahatani kopi sebesar 0,42 Ha. Untuk luas lahan usahatani kakao pada saat penelitian rata-rata adalah sebesar 0,57 Ha. Hal ini menunjukkan banyaknya petani melakukan substitusi lahan untuk usahatani kakao. Penambahan luas lahan ini berasal dari berbagai sumber yaitu dari pembelian lahan dan warisan yaitu masing-masing untuk pembelian lahan sebanyak 35 orang, untuk warisan sebanyak 22 orang.

Setelah dilakukan wawancara langsung kepada petani di Desa Bukit Menyan Kecamatan Bermani Ilir Kabupaten Kepahiang, mempunyai berbagai kendala dan mematikan semangat petani kopi yaitu produksi yang rendah mengakibatkan ketidakseimbangan antara biaya perawatan dengan produksi yang dihasilkan. 
Tabel 11. Persentase Luas Lahan Yang Mengalami Substitusi Usahatani Mulai Tahun 2011 Sampai Tahun 2016

\begin{tabular}{lcccc}
\hline $\begin{array}{l}\text { Persentase luas lahan } \\
\text { yangdisubstitusikan (\%) }\end{array}$ & $\begin{array}{c}\text { Jumlah } \\
\text { (Orang) }\end{array}$ & & $\begin{array}{c}(\%) \\
\text { Rata- }\end{array}$ & Kisaran \\
\hline Besar (75-100) & 37 & 64.91 & 75.07 & $25-100$ \\
Sedang (50-74) & 13 & 22.80 & & \\
Kecil (25-49) & 7 & 12.28 & \\
\hline Jumlah & 57 & 100 & & \\
\hline
\end{tabular}

Sumber : Data primer diolah, April 2016

Kemudian musim panen yang hanya 1 (satu) kali setahun sementara kebutuhan harus dipenuhi setiap saat, dengan menanan tanaman kakao di sebagian lahan dapat mgurangi resiko lama panen tersebut. Selain itu alasan ekonomi menjadi latar belakang substitusi lahan dari usahtani kopi ke usahatani kakao. Sebab, tingkat keuntungan (land rent) yang diperoleh dengan mensubstitusikan usahatani memiliki keuntungan ganda yaitu dari usahatani kopi dan usahatani kakao sehingga dapat menekan kehidupan keluarga petani karena biaya hidup semakin melambung tinggi.

\section{Pendapatan Sebelum Substitusi Usahatani}

Pendapatan merupakan selisih antara total penerimaan dengan total biaya yang dikeluarkan selama proses produksi. Analisis pendapatan memerlukan data penerimaan atau pendapatan kotor dan biaya. Penerimaan adalah seluruh pendapatan yang diperoleh selama satu periode yang diperhitungkan dari hasil penjualan atau penaksiran kembali. Biaya didefinisikan sebagai sesuatu yang dikorbankan oleh seseorang dalam proses produksi serta membawanya menjadi produk.

Pendapatan merupakan ukuran keuntungan dan faktor yang penting karena keberhasilan suatu usaha dapat dilihat dari besar pendapatannya karena terpenuhinya atau tidak terpenuhinya kebutuhan hidup atau rumah tangga dapat dilihat dari besarnya pendapatan. Semakin kecil pendapatan maka semakin sulit untuk memenuhi kebutuhan sehari-hari. Besarnya pendapatan sebelum melakukan substitusi usahatani kopi dapat dilihat pada tabel 12. 


\section{Tabel 12 Pendapatan Sebelum Substitusi Usahatani}
No Uraian
Pendapatan Sebelum Substitusi
Usahatani (Rp/Tahun)

\begin{tabular}{llr}
\hline 1. & Penerimaan & 17.889 .473 \\
2. & Total Biaya & 2.059 .649 \\
& Pendapatan & $\mathbf{1 5 . 8 2 9 . 8 2 4}$
\end{tabular}

Sumber: Data Primer diolah 2016

Berdasarkan tabel 12 diketahui bahwa rata-rata pendapatan sebelum melakukan substitusi usahatani kopi adalah sebesar Rp 15.829.000. Setiap petani kopi memiliki perbedaan pendapatan karena dipengaruhi oleh perbedaan jumlah biaya yang dikeluarkan dan perbedaan penerimaan yang diperoleh dalam kegiatan usahatani kopi. Pendapatan dapat ditingkatkan dengan meminimumkan biaya-biaya yang harus dikorbankan untuk kegiatan usahatani kopi.

Dari hasil penelitian yang telah dilakukan terhadap petani kopi sebelum substitusi dapat dilihat bahwa rata-rata pendapatan sebelum substitusi usahatani adalah sebesar Rp 15.829.000 per tahun dengan pendapatan terendah $\mathrm{Rp} 5.100,000$ dan pendapatan tertinggi $\mathrm{Rp}$ 45.900.000 per tahun. Tinggi rendahnya pendapatan dipengaruhi oleh biaya-biaya yang dikeluarkan untuk kegiatan usahatani kopi, selain itu luasnya lahan yang dimiliki oleh petani. Sebaran pendapatan responden tersebut secara rinci disajikan pada tabel 13.

Dari Tabel 13, terlihat bahwa pendapatan responden yang paling banyak adalah antara Rp.5.100.000 - Rp.18.700.000 yaitu berjumlah 37 orang atau $64.91 \%$. Sedangkan pendapatan responden paling sedikit antara 32.300.000 - 45.900.000 yaitu berjumlah 3 responden atau 5.26\%. Rata-rata pendapatan responden adalah Rp 15.829.000 per tahun.

Tabel 13. Distribusi Pendapatan Usahatani Kopi Sebelum Substitusi

\begin{tabular}{clcc}
\hline No & \multicolumn{1}{c}{ Kelas Pendapatan } & Jumlah (jiwa) & Persen (\%) \\
\hline 1 & $5.100 .000-18.700 .000$ & 37 & 64.91 \\
2 & $18.700 .000-32.300 .000$ & 17 & 29.82 \\
3 & $32.300 .000-45.900 .000$ & 3 & 5.26 \\
\hline & $\begin{array}{l}\text { Rata-rata Rp 15.829.000 } \\
\text { Jumlah }\end{array}$ & 57 & 100
\end{tabular}

Sumber: Data Primer diolah, 2016 
Dari data yang diperoleh terlihat bahwa sebagian besar petani berpenghasilan rendah. Hal ini diakibatkan oleh produksi yang rendah mengakibatkan ketidakseimbangan antara biaya perawatan dengan produksi yang dihasilkan. Kemudian musim panen yang hanya satu kali setahun sementara kebutuhan harus dipenuhi setiap saat, harga pupuk terus melambung, upah tenaga kerja harus dibayar, sedangkan hasil yang diperoleh sedikit. Kendala lain yang dihadapi petani adalah kesenjangan harga pasar yang terjadi setiap kali panen. Para petani kopi sama sekali tak berdaya karena jauh sebelum panen kadang-kala sudah terbelit utang dari para rentenir. Belitan utang ini sulit dihindari karena petani juga terkendala dalam hal modal usaha, seperti untuk membeli obat-obatan, pupuk, dan pemeliharaan tanaman. Daripada kopi busuk di pohon, akhirnya petani terpaksa melepas dengan harga yang lebih murah. Hal ini menyebabkan mematikan animo petani untuk lebih mengintensifkan penanaman kopi.

\section{Pendapatan Sesudah Substitusi Usahatani}

Pendapatan merupakan ukuran keuntungan dan faktor yang penting karena keberhasilan suatu usaha dapat dilihat dari besar pendapatannya karena terpenuhinya atau tidak terpenuhinya kebutuhan hidup atau rumah tangga dapat dilihat dari besarnya pendapatan. Semakin kecil pendapatan maka semakin sulit untuk memenuhi kebutuhan sehari-hari. Besarnya pendapatan sesudah melakukan substitusi usahatani kopi dapat dilihat pada tabel 14. Diketahui bahwa rata-rata pendapatan setelah melakukan substitusi usahatani kopi sebesar Rp 23.248.000 per tahun. Setiap petani kopi memiliki perbedaan pendapatan karena dipengaruhi oleh perbedaan jumlah biaya yang dikeluarkan dan perbedaan penerimaan yang diperoleh dalam kegiatan usahatani kopi. Pendapatan dapat ditingkatkan dengan meminimumkan biaya-biaya yang harus dikorbankan untuk kegiatan usahatani kopi.

Dari hasil penelitian yang telah dilakukan terhadap petani kopi sesudah substitusi dapat dilihat bahwa rata-rata pendapatan sesudah substitusi usahatani adalah sebesar Rp Rp 23.248.000 per tahun dengan pendapatan terendah $\mathrm{Rp}$ 12.000.000 per tahun dan pendapatan tertinggi $\mathrm{Rp} \quad 49.280 .000$ per tahun. Berdasarkan informasi dari responden tinggi rendahnya pendapatan dipengaruhi oleh biaya-biaya yang dikeluarkan untuk kegiatan usahatani kopi, selain itu luasnya lahan yang dimiliki oleh petani. Sebaran pendapatan responden tersebut secara rinci disajikan pada tabel 15. 
Tabel 14 Pendapatan Sesudah Substitusi Usahatani
No Uraian
Pendapatan Sesudah Substitusi
Usahatani (Rp/Tahun)

\begin{tabular}{lll}
\hline 1. & Penerimaan & 36.428 .000 \\
2. & Total Biaya & 12.916 .000 \\
& Pendapatan & $\mathbf{2 3 . 2 4 8 . 0 0 0}$
\end{tabular}

Sumber: Data Primer diolah 2016

Tabel 15. Distribusi Pendapatan Usahatani Kopi Sesudah Substitusi

\begin{tabular}{|c|c|c|c|}
\hline No & Kelas Pendapatan & Jumlah (jiwa) & Persen $(\%)$ \\
\hline 1 & $12.000 .000-24.426 .000$ & 38 & 66.67 \\
\hline 2 & $24.426 .000 .-36.853 .000$ & 12 & 21.05 \\
\hline 3 & $36.853 .000-49.280 .000$ & 7 & 12.28 \\
\hline \multicolumn{4}{|c|}{ Rata-rata $\mathrm{Rp} 23.248 .000$} \\
\hline & Jumlah & 57 & 100 \\
\hline
\end{tabular}

Sumber: Data Primer diolah, 2016

Dari Tabel 15, terlihat bahwa pendapatan responden yang paling banyak adalah kelas pendapatan antara Rp.12.000.000 Rp.24.426.000 yaitu berjumlah 38 orang atau $66.67 \%$. Sedangkan pendapatan responden paling sedikit antara 36.853.000 - 49.280.000 yaitu berjumlah 7 responden atau $12.28 \%$. Rata-rata pendapatan responden adalah $\mathrm{Rp}$ 23.248.000 per tahun.

Hal ini menunjukkan bahwa usahatani kakao berperan dalam perekonomian keluarga. Mereka menjalani substitusi usahatani karena adanya dorongan untuk dapat meningkatkan pendapatan keluarga, sehingga keuangan keluarga tidak hanya bersumber dari usahatani kopi yang musim panennya hanya satu kali dalam satu tahun. Kondisi demikian merupakan dorongan yang kuat bagi petani kopi untuk mensubstitusikan usahatani mereka. Alasan ekonomi menjadi latar belakang substitusi lahan dari usahtani kopi ke usahatani kakao. Sebab, tingkat keuntungan (land rent) yang diperoleh dengan mensubstitusikan usahatani memiliki keuntungan ganda yaitu dari usahatani kopi dan usahatani kakao sehingga dapat menekan kehidupan keluarga petani kopi.

Hasil penelitian ini sejalan dengan hasil penelitian Syafuan (2007) tentang perubahan pola usahatani padi ke 
usahatani cabai, yang menyatakan bahwa faktor pendapatan petani berpengaruh terhadap perubahan pola usahatani padi ke usahatani cabai. Semakin tinggi pendapatan dari usahatani cabai maka semakin banyak petani yang melakukan perubahan pola usahatani sehingga lahan yang dimiliki untuk usahatani padi semakin sedikit.

Dari analisis pendapatan petani sebelum dan sesudah substitusi terlihat peningkatan yang lebih baik dibandingkan dengan sebelum substitusi, dengan demikian kegiatan substitusi dapat meningkatkan ekonomi rumah tangga petani. Persentase peningkatan pendapatan petani dapat dilihat pada tabel 16.

Setelah dilakukan kegiatan substitusi terlihat peningkatan pendapatan petani sebesar 46,86\%. Hal ini dapat dikatakan persentase peningkatan petani cukup besar setelah dilakukan substitusi usahatani. Mereka menjalani substitusi usahatani karena adanya dorongan untuk dapat meningkatkan pendapatan keluarga, sehingga keuangan keluarga tidak hanya bersumber dari usahatani kopi yang musim panennya hanya satu kali dalam satu tahun.

Menurut Sinungan (2003), menyatakan bahwa untuk standar peningkatan pendapatan petani, tergantung kepada pendapatan sebelum dan sesudah melakukan usahatani atau pendapatan sebelum dan sesudah melakukan transformasi dalam pengalokasian sumberdaya lahan dari satu penggunaan ke penggunaan lainnya. Setiap usahatani memiliki perbedaan standar peningkatan pendapatan. Namun menurut Sinungan (2003), peningkatan pendapatan ini dapat digolongkan berdasarkan kategorikategori berikut :

Sangat rendah $\quad: 1-20 \%$

Rendah : $: 21-40 \%$

Sedang atau Cukup : $41-60 \%$

Tinggi $: 61-80 \%$

Sangat tinggi $\quad: \geq 80 \%$

\section{Tabel 16 Presentase Peningkatan Pendapatan Petani}

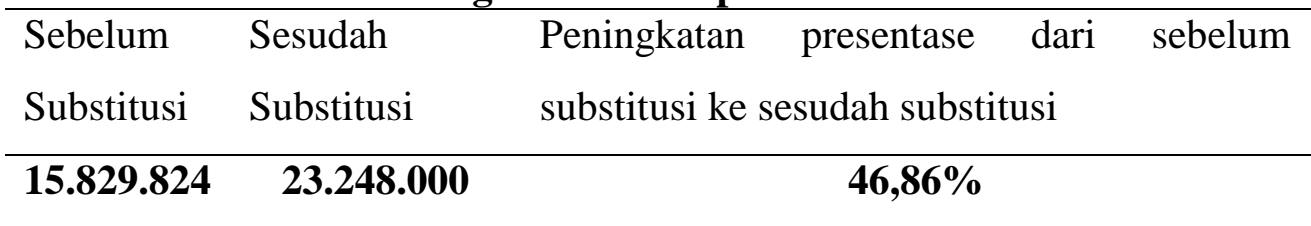

Sumber: Olahan Data Primer, 2015 
Untuk kriteria pendapatan yang ditetapkan dalam seminar pendaptan nasional dan salah satu pokok adalah batasan tingkat pendapatan untuk tingkat pendapatan untuk kriteria pendapatan rendah sedang dan tinggi sebagai berikut (Sinungan, 2003) :

1. Kriteria untuk pendapatan rendah Penduduk yang pendapatan rendah yaitu Rp.1.000.000 - Rp.10. 000.000. pertahun atau rata-rata Rp. 750. 000 perkapita perbulan; tidak memiliki pekerjaan tetap; tidak memiliki tempat tinggal tetap (Sewa); tingkat pendidikan yang terbatas

2. Kriteria untuk pendapatan sedang Penduduk yang berpendapatan sedang yaitu Rp. 10.000.000 - Rp. 25.000.000 Rp.1.250. 000.000 perkapita perbulan; memiliki pekerjaan tetap; memiliki tepat tinggal yang sederhana; memiliki tingkat pendidikan.

3. Kriteria untuk pendapatan tinggi Penduduk bependapatan tinggi yaitu Rp. 25. 000.000-Rp. 50. 000.000 atau rata-rata $\mathrm{Rp} 2.083 .333$ perkapita perbulan; memiliki lahan dan lapangan kerja; memiliki tempat tinggal tetap; memiliki tingkat pendidikan.

\section{KESIMPULAN}

Alasan petani melakukan substitusi usahatani disebabkan oleh 3 (tiga) faktor yaitu jumlah tanggungan keluarga, penerimaan usahatani kopi, dan faktor lain-lain. Alasan karena jumlah tanggungan keluarga adalah sebanyak 14 orang atau sebanyak $24.50 \%$. Sedangkan alasan petani karena penerimaan usahatani kopi adalah sebanyak 29 orang atau sebanyak 50.87\%, dan untuk alasan pengalaman berusahatani adalah sebanyak 14 orang atau sebanyak $24.50 \%$. Luas lahan petani yang disubstitusikan dari usahatani kopi ke usahatani kakao di Desa Bukit Menyan Kecamatan Bermani Ilir Kabupaten Kepahiang propinsi Bengkulu memiliki rata-rata $75.07 \%$ dari total luas lahan yang dimiliki oleh petani. Pendapatan rata-rata petani kopi sebelum melakukan substitusi usahatani adalah sebesar adalah sebesar Rp 15.829.000 per tahun dengan pendapatan terendah $\mathrm{Rp}$ 5.100,000 dan pendapatan tertinggi Rp 45.900.00 per tahun. Pendapatan rata-rata petani kopi sesudah melakukan substitusi usahatani adalah sebesar Rp 23.248.000 per tahun dengan pendapatan terendah $\mathrm{Rp}$ 12.000.000 per tahun dan pendapatan tertinggi Rp 49.280.000 per tahun.

\section{DAFTAR PUSTAKA}

Arikunto, Suharsimi. 2006. Prosedur Penelitian Suatu Pendekatan Praktik. Rineka Cipta. Jakarta.

Ambarini, D.Y. 2002. Faktor-faktor yang Mempengaruhi Pendapatannya Pemetik Teh (Studi kasus di Desa Air Sempiang Kecamatan Kepahiang kabupaten Rejang Lebong). Skripsi. Jurusan Sosial Ekonomi Pertanian. Fakultas 
Pertanian. Universitas Bengkulu. Bengkulu. Tidak Dipublikasikan.

Awal, Efli. 2003. Analisis Model Proses Pengambilan Keputusan Konsumen dalam Memilih Pengecer Pestisida di Kota Manna Bengkulu Selatan. Skripsi Jurusan Agribisnis. Fakultas Pertanian. Universitas Bengkulu. Tidak dipublikasikan.

Ashari. 2003. Tinjauan Tentang

Perubahan Penggunaan Lahan

Sawah Ke Non Sawah Dan

Dampaknya Dipulau Jawa. Forum

Penelitian Agro Ekonomi 21 (2) : 83-98.

Betharia. 2001. Analisis Sikap Dan Hubungannya Dengan Perilaku Konsumen Makanan Siap Saji (Fast Food) California Fried Chicken Di Kota Bengkulu. Skripsi. Jurusan Sosial Ekonomi Pertanian. Fakultas Pertanian. Universitas Bengkulu. Tidak Dipublikasikan.

Daniel. 2003. Budidaya Taman Kopi. Penerbit Kanisius. Jakarta.

Boediono, 2002. Ekonomi Mikro. Universitas Gadjah Mada. Yogyakarta.

Handayani M Th dan Artini Ni W P, 2009. Kontribusi Pendapatan Ibu Rumah Tangga Pembuat Makanan Olahan Terhadap Pendapatan Keluarga. Piramida Vol V No. 1.

Hernanto, 2004.http $\quad$ www.Aspek-Aspek Pendapatan Ekonomi. Badan Penelitian dan pengembangan Pertanian. Jakarta. Diakses 14 Januari 2016.

Juliarahmi, I. 2002. Analisis FaktorFaktor Yang Berhubungan Dengan Luas Lahan Yang Dikonversi Dari Usahatani Padi Ke Usahatani Ikan Mas (Studi Kasus Di Kecamatan Padang Jaya Kabupaten Bengkulu Utara). Skripsi. Jurusan Sosial Ekonomi Pertanian. Fakultas
Pertanian. Universitas Bengkulu. Tidak Dipublikasikan.

Kustiwan, I. 2001. Perubahan Lahan di Pantai Utara Jawa. LP3S. Prisma. Jakarta.

Muchdarsyah Sinungan, 2003, Produktivitas dan Pendapatan

Masyarakat, Bumi Aksara, Jakarta.

Mubyarto. 2001. Perekonomian Indonesia. BPFE, Yogyakarta.

Muljana. 2001. Budidaya Kakao. Rajawali Press. Jakarta.

Najiyati Sri dan danarti. 2005. Kopi Budidaya dan Penanganan Lepas Panen. Penerbit PT Penebar Swadaya. Jakarta.

Nasaruddin. 2004. Budidaya Kakao dan Beberapa Aspek Fisiologinya. Kanisius. Jakarta.

Nurmanaf, A. R. 2006. Peranan Sektor Luar Pertanian Terhadap Kesempatan Dan Pendapatan Di Pedesaan Berbasis Lahan Kering. Jurnal SO CA Volume 8. No 3.November 2008, hal 318-322.

Siregar Nurmalina. 2009. Analaisis Finansial Industri Pengolahan Dodol Salak dan Prosepek Pengembangannya di Kabupaten Tapanuli Selatan. Universitas Sumatera.

Pratiwi, H. 2011. Peran Perempuan Untuk Pendapatan Keluarga Makin

Signifikan.http://femalekompas.co $\mathrm{m} / \mathrm{read} / 2013 / 01 / 17 / 094 /$ peranpere mpuan untuk pendapatan keluarga. Diakses pada tanggal 8 Desember 2013.

Rahardjo, Pudji. 2012.Panduan Budidaya dan Pengolahan Kopi Arabika dan Robusta. Penebar Swadaya. Jakarta 
Riski, 2001. Analisis Substitusi Usahatani Jeruk Usahatani Kelapa Sawit Di Pedesaan Ujung Gading Kabupaten Pasaman Barat Provinsi Sumatera Barat. Jurnal Penelitian Universitas Bengkulu Volume VII Nomor 2 Juli 2007. Fakultas Pertanian Universitas Bengkulu. Bengkulu.

Soejono Soekanto. 2001. Teori Sosiologi

Tentang Perubahan Sosial. PN, Ghalia Indonesia.

Soemardi, M. 2002. Kemiskinan Dan Kebutuhan. Rajawali Press. Jakarta.

Syafuan,I. 2007. Analisis Faktor-Faktor Yang Berhubungan Dengan Perubahan Pola Usahatani Padi Ke Usahatani Cabai Di Desa Penanjung Panjang Kecamatan Tebat Karai Kabupaten Kepahiang. Skripsi Fakultas Pertanian Jurusan Sosial Ekonomi Pertanian. UNIB. Bengkulu. Tidak dipublikasikan.
Suyanto, 2008. Metode Penelitian Sosial. Kencana Prenada Media. Indonesia.

Widiono, Septri. 2008. Konversi Lahan dan Struktur Produksi Kebun: studi Kasus Terbentuknya Perkebunan Kelapa Sawit. Pada Dua Desa Sawah Etnis Serawai dan Jawa di Kabupaten Seluma, Propinsi Bengkulu. Jurnal Agrisep: Bengkulu. Vol. 7 No. 2 Maret 2008: 54-71.

Yuanda,Y. 2004. Studi Tentang FaktorFaktor Yang Mempengaruhi Perubahan Lahan Kopi Di Propinsi Bengkulu. Skripsi Fakultas Pertanian Jurusan Sosial Ekonomi Pertanian. UNIB. Bengkulu. Tidak dipublikasikan.

Yusianto. 2000. Pasca Panen Kakao. Pusat Penelitian Kopi dan Kakao, Jember. Indonesia.

Zainudin. 2010. Budidaya Kakao. Pusat Penelitian Kopi dan Kakao, Jember. Indonesia. 